\title{
ペーパークロマトグラフ法による大根葉の \\ 遊離アミノ酸に關寸る研究 \\ Studies of the free amino acids of Radish leaf \\ by paper chromatography
}

(昭和 27 年 10 月 28 日受利)

$\begin{array}{cc}\text { 嘿 滕 恒 行 } & \text { 渡 部 俊夫 } \\ \text { (Tsuneyuki Saito) } & \text { (Toshio Watanabe) }\end{array}$

\section{緒言}

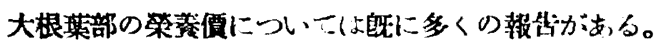

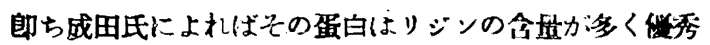
でおり，鈴木氏によれば無譏分が多く大根とけ分布が基 つており，藤田氏によればビタミン含喤多く，岩田氏は ビタミンC含量，無譏成分含量”゙の他が綜合的に检討 し大いに利用すへきすのと賞している。

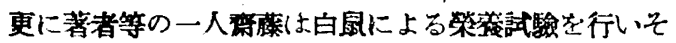

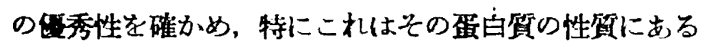
事を認めた(1)。

一方大根及びその皮の遊盛了ミ，酸分布については， 武衤氏がンーーバークロマトグラフ法により多くの根茶類 を調ベた報告中に記されている(2)。

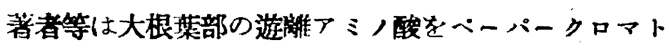
グラフ法により調ハ，之を大根及び皮の部分の遊踓つミ

八酸と比べてみた。

\section{實驗方法}

（1）供䭼材料 秋大根 (宮重大根) について只の藮 を一度水洗し生のもの乾燥したものを䏳，大根は一度 水洗し身及び皮に分けて用い\%。

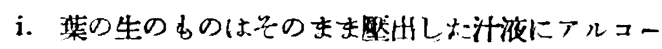

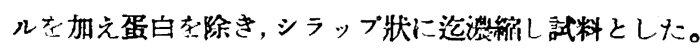

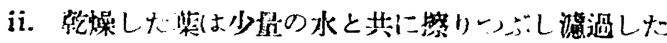
激に更にアルコールた加えて盆白芯除き，シラッブ状ま て篊剂し試料とした。

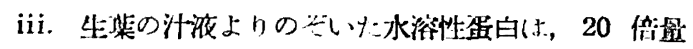

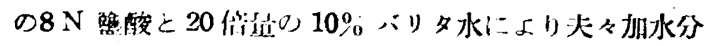
解し、中和, 㴚衫し二試料とした。

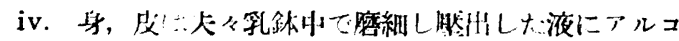
一几在加之て蛋白在除き浱綃して大々試料とした。

（2）一次元ペーパークロマトクラフ法 $7_{x}$ ハール (20\% 含水), ピリヂン (10\% フニリン会有)，ブタノー

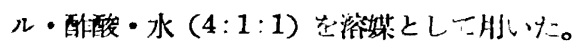

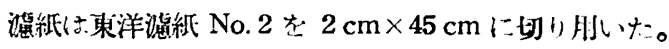

（3）二次元ペーパークロマトグラフ洼ブタノール・
酶酸・水 $(4: 1: 1)$ とっェール(20\% 含水)によつた。 之に使用した滤科(東洋嬑紙 No.2) の寸法は常法通り $30 \mathrm{~cm}^{2}$ のものの他に, $15 \mathrm{~cm}$ ”の大きさのすの(3)を用いた。

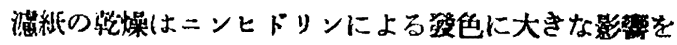

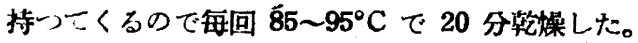

（4）磪战 上記試料をべーパークロマトグラフ法に より一次元，二次元に展開させ，ニンヒドリンにより登 色させ，その位置と色調に上り確㑇した。份確㑇に當つ

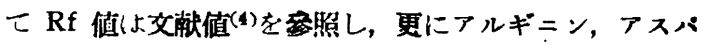
ラギン, アスパラギン酸, グリシン,グルタミン酸, メ チオニン, ヒスチヂン, ロイシン, チロジン,トリプト ファン, バリンを夫々単独に, 又混合し, 更に試料に混 じて判定に凟した。

アミノ酸の Rf 値は溫度の答化により必ずしも一定し ない。著者等は上記の㧚紙, 溶媒を用い15〜20 でフ ，酸の Rf 値を求めて表 I の樣な值を得た。此の保件で は照した交献值と大きな差哄のない、事，この溫度の籍 阅ではその差により餘り䇾化のない韦，しかもその Rf 値のずれは湘定したすへててのてミ，酸について相對的に 大となり小となるものである事を確認に先だち知つた。

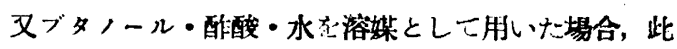
等を混合し丁長く㯰くとェステル化し Rf 値か堂つてく るのて，混合後7日目迄のものを濑用した。

舒ピリジンを溶媒とした場合は發色が餘り明膫でなく

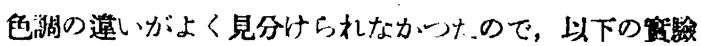
に於いても餘り伐胡しなかつた。

\begin{tabular}{|c|c|c|c|c|c|c|}
\hline \multicolumn{4}{|c|}{ 溶出 } & $7 x<-ル$ & $\begin{array}{l}\text { ブタノー } \\
\text { ル・酰酸 }\end{array}$ & ピリチン \\
\hline$タ ゙$ & リ & $\dot{z}$ & ン & $\begin{array}{c}0.38 \sim 0.40 \\
(0.40)\end{array}$ & $\begin{array}{c}0.28 \sim 0.31 \\
(0.32)\end{array}$ & \\
\hline 六 & & リ & ン & $\begin{array}{c}0.74 \sim 0.77 \\
(0.74)\end{array}$ & $\begin{array}{c}0.53 \sim 0.56 \\
(0.53)\end{array}$ & \\
\hline 口 & 1 & & ン & $\begin{array}{c}0.79 \sim 0.84 \\
(0.86)\end{array}$ & $\begin{array}{c}0.68 \sim 0.71 \\
(0.69)\end{array}$ & $\underset{(0.65)}{0.66 \sim 0.71}$ \\
\hline f & 口 & $\ddot{E}$ & ン & $\begin{array}{c}0.64 \sim 0.67 \\
(0.66)\end{array}$ & $\begin{array}{c}0.52 \sim 0.56 \\
(0.59)\end{array}$ & $\begin{array}{l}0.72 \sim 0.77 \\
(0.74)\end{array}$ \\
\hline$r$ & & & & $\begin{array}{c}0.12 \sim 0.14 \\
(0.12)\end{array}$ & $\begin{array}{c}0.20 \sim 0.24 \\
(0.26)\end{array}$ & $\begin{array}{c}0.15 \sim 0.18 \\
(0.16)\end{array}$ \\
\hline
\end{tabular}




\begin{tabular}{|c|c|c|c|}
\hline 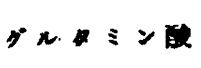 & $\begin{array}{c}0.18 \sim 0.21 \\
(0.20)\end{array}$ & $\begin{array}{c}0.27 \sim 0.31 \\
(0.32)\end{array}$ & \\
\hline$x * t=2$ & $\begin{array}{c}0.78 \sim 0.81 \\
(0.83)\end{array}$ & $\begin{array}{c}0.51 \sim 0.54 \\
(0.56)\end{array}$ & \\
\hline リ F゙ & $\begin{array}{c}0.40 \sim 0.42 \\
(0.49)\end{array}$ & $\begin{array}{c}0.11 \sim 0.12 \\
(0.12)\end{array}$ & $\begin{array}{c}0.14 \sim 0.18 \\
(0.14)\end{array}$ \\
\hline ヒx & $\begin{array}{c}0.66 \sim 0.69 \\
(0.70)\end{array}$ & $\begin{array}{c}0.18 \sim 0.22 \\
(0.25)\end{array}$ & $\begin{array}{c}0.33 \sim 0.35 \\
(0.34)\end{array}$ \\
\hline$\Gamma x \neq=2$ & $\begin{array}{c}0.48 \sim 0.51 \\
(0.48)\end{array}$ & $\begin{array}{c}0.11 \sim 0.14 \\
(0.13)\end{array}$ & $\begin{array}{c}0.17 \sim 0.20 \\
(0.14)\end{array}$ \\
\hline トyブ & $\begin{array}{c}0.77-0.81 \\
(0.80)\end{array}$ & - & $\begin{array}{c}0.68 \sim 0.70 \\
(0.66)\end{array}$ \\
\hline$T=$ & $\begin{array}{c}0.41 \sim 0.45 \\
(0.42)\end{array}$ & $\begin{array}{c}0.36 \sim 0.40 \\
(0.36)\end{array}$ & \\
\hline
\end{tabular}

新.（）内は照した文献值。

\section{實驗耛果改ひ考察}

(1) 一央元ペーパークロマトソラフ法 前記の要領 で一夫元ベーパークロマトグラフ法を行つた。各浴媒を 用いて湤定した Rf 值は夷の通りである。

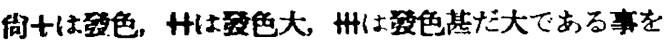

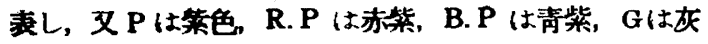
色，「は黄色，Oは授色の色調を表わす。

i. .フェノールを使用した坦合

生藮： $0.09,0.14,0.21,0.34,0.39,0.43,0.49,0.52,0.58$, $\begin{array}{lllllllll}\text { G.P } & \mathbf{P} & \mathbf{P} & \mathbf{P} & \mathbf{P} & \mathbf{G} & \mathbf{P} & \mathbf{P} & \mathbf{P}\end{array}$ $+\mathrm{HH}+\mathrm{HH} H++$ $0.64,0.69,0.74,0.78,0.83,0.89,0.92$

$\begin{array}{lllllll}G & P & P & P & P & Y & P \\ H & + & + & + & + & H & +\end{array}$

较裸蓝： $0.04,0.09,0.13,0.15,0.22,0.30,0.35,0.41$, $\begin{array}{llllllll}\text { G.P } & \mathbf{P} & \mathbf{B} & \mathbf{G} & \mathbf{P} & \mathbf{G} & \mathbf{P} & \text { R.P }\end{array}$ $++H H+H++t$ 0.43, 0.47, 0.54, 0.64, 0.68, 0.71, 0.78, 0.80, $\begin{array}{llllllll}\mathbf{G} & \mathbf{P} & \mathbf{R} . \mathbf{P} & \mathbf{O} & \mathbf{P} & \mathbf{P} & \mathbf{P} & \mathbf{P}\end{array}$ $++t+t+t+$ $0.86,0.91$

$$
\begin{array}{ll}
Y & P \\
H & +
\end{array}
$$

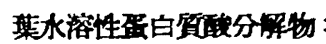

$0.05,0.09,0.12,0.16,0.22,0.28,0.33,0.39,0.44,0.47$, $\begin{array}{lllllllll}\text { G.P G.P } & \text { P } & \text { G } & \text { P } & \text { G } & \text { P } & \text { R.P } & \text { G } & \text { P }\end{array}$ $++H H+H+H H+$ $0.62,0.67,0.75,0.86,0.91$

$$
\begin{array}{lllll}
P & G & P & Y & P \\
+ & + & + & H & +
\end{array}
$$

身: $0.05,0.10,0.13,0.16,0.22,0.27,0.35,0.39,0.43$, $\begin{array}{llllllll}\text { R.P R.P } & P & \text { R.P } & \text { P } & \text { P } & \text { P } & \text { R.P } & \text { P }\end{array}$ $++t++++H H$ $0.49,0.54,0.58,0.66,0.69,0.77,0.81,0.86,0.90$

$$
\begin{array}{lllllllll}
\mathbf{P} & \mathbf{P} & \mathbf{P} & \mathbf{G} & \mathbf{P} & \mathbf{P} & \mathbf{P} & \mathbf{Y} & \mathbf{P}
\end{array}
$$$$
++t+t+t+t
$$

皮： $0.09,0.13,0.16,0.21,0.27,0.36,0.40,0.43,0.50$,

$$
\begin{array}{lllllllll}
\mathbf{G} & \mathbf{P} & \mathbf{R}, \mathbf{P} & \mathbf{P} & \mathbf{P} & \mathbf{P} & \mathbf{P} & \mathbf{G} & \mathbf{P}
\end{array}
$$$$
+\mathrm{H}+\mathrm{t}+\mathrm{H}+\mathrm{H}
$$

$0.53,0.58,0.65,0.68,0.75,0.81,0.86$

$$
\begin{array}{lllllll}
P & P & G & P & P & P & Y \\
+ & + & + & H & + & + & H
\end{array}
$$

ii.ブタノール・醋酸を做用しな場合

生葉： $0.11,0.13,0.20,0.23,0.27,0.31,0.34,0.38,0.42$, $\begin{array}{lllllllll}\text { R.P } & \text { P } & \text { R.P } & \text { P } & \text { P } & \text { P } & \text { P } & \text { Y.G } & \text { Y }\end{array}$ H H H H $H$ H H H $0.52,0.56,0.70,0.73$

$$
\begin{array}{lll}
\text { P } & \text { P } \\
+ & + & +
\end{array}
$$

乾媒渠： $0.04,0.10,0.12,0.19,0.21,0.26,0.29,0.34$, $\begin{array}{lllllll}\text { G.P G.P } & P & P & P & P & P & \text { B.P }\end{array}$ $+H$ H H H ++ $0.39,0.41,0.51,0.56,0.68,0.72$

$$
\begin{array}{cccccc}
O & Y & P & G . P & P & P \\
H & H H & + & H & + & +
\end{array}
$$

望蛋白酸分解物： $0.04,0.09,0.12,0.19,0.22,0.27,0.35$,

$$
\begin{array}{ccccccc}
\text { R.P } & P & P & G . P & P & P & P \\
+ & H & H & + & + & + & H \\
0.39, & 0.41, & 0.52, & 0.58, & 0.68, & 0.72 & \\
\text { G } & Y & P & G & P & P & \\
\dot{H} & H & H & + & + & +
\end{array}
$$

身: $0.04,0.09,0.11,0.19,0.22,0.27,0,30,0.36,042$,

$\begin{array}{llllllll}\text { G.P R.P } & P & \text { R.P } & P & P & \text { G.P } & \text { P } & \text { Y }\end{array}$

$$
++t+t+H+H+
$$

$0.53,0.58,0.70,0.75$

$$
\begin{array}{lll}
P & \text { G.P } & P \\
+ & + & +
\end{array}
$$

皮：0.04, 0.09, 0.12, 0.19, 0.22;0.27, 0.34, 0.38, 0.42,

$\begin{array}{lllllllll}\text { R.P } & \mathbf{P} & \mathbf{P} & \text { R.P } & \mathbf{P} & \mathbf{P} & \mathbf{P} & \mathbf{O} & \mathbf{Y}\end{array}$

$++H+H+H+H H$

0.56

G.P

$+$

iii. ビリジンを使用した場合 (色調不明㮩)

生菜： $0.120 .16 \quad 0.18 \quad 0.24 \quad 0.31 \quad 0.34 \quad 0.44 \quad 0.51 \quad 0.62$

$$
\begin{aligned}
& +H+H++H+H++ \\
& 0.700 .740 .82 \\
& H++
\end{aligned}
$$

（2）二次元ペーパークロマトグラフ法 各試料につ いて前記の要領で二次元べーハークロマトグラフ法を行 い, 夫ょ次図の如きクロマトグラム灰得た。

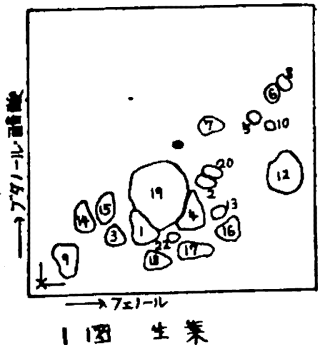

1 $13 \pm \pm$ 策

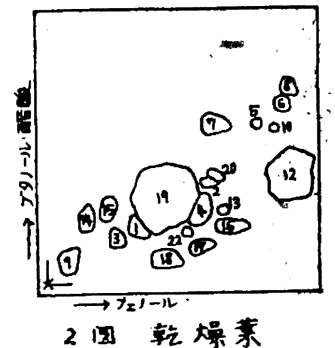

( 221$)$ 


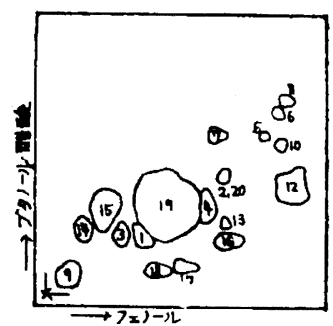

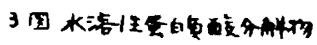

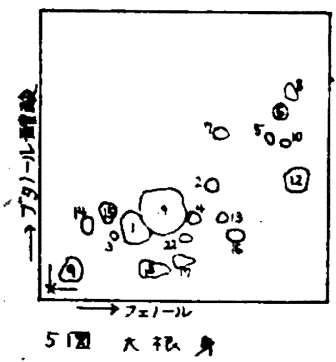

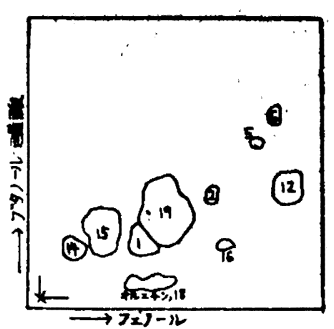

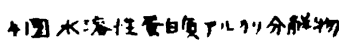

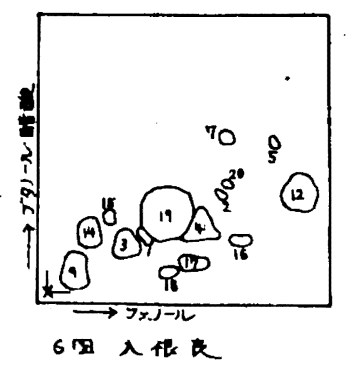

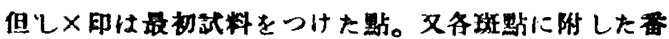

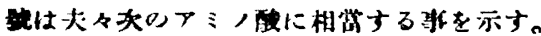

1.グリ シ ン 9. シ ス チ

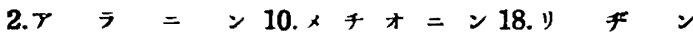

3.七 リ ン 11.トリプトフアン 19.アスパラギン

4.スレオ $ス$ オ 12.プロリン20.゙ルタミン

5.パ リ ン 13.オキシプロリン21.グルタチオン

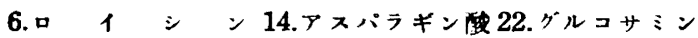

7.千 ロ ジン 15.グルタミン股

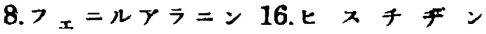

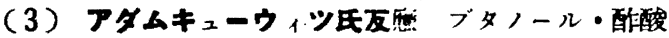
では众㤕不能でむるトリブトファンの存在さより明唯に 知る䈔に、アダムキューウィツ氏反隹をも用いた。

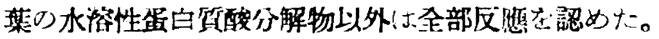

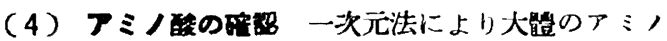
酸分布を知つに。然し二次元法によーう上り正確にーミ

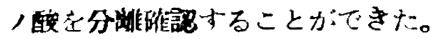

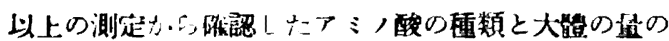
開係は，头ヶの試料について表 I の通りでむる。

㘳Iアミ八酸の分布

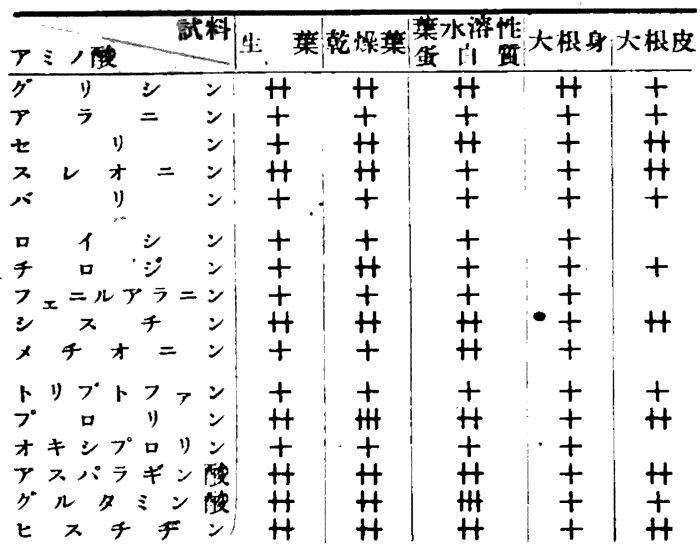

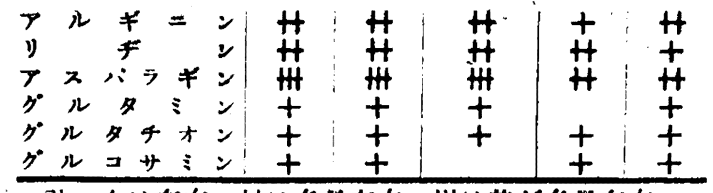

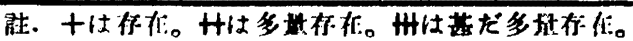

\section{(5) 苛 实}

i. 葉の中に遊離の形で存在するてミノ酸は種類力洺 く，特にブロリン,アスハラギンの赀洺く、グリシン, スレオニン, シスチン,アスパラギン酸,グルタミン能, ヒスチヂン,アルギニン、リヂンがとに次ぐ。

ii. 染の水洛性蛋白はグルタミン酸，フスハラギンに 富む。染の遊漼つミ，酸に比へててて分有に大きな彎り はない。

iii. 大根第の部分に存在寸る遊㸡アミノ酸はグリシ

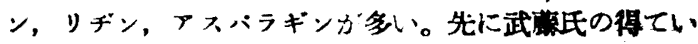
る結果に見るとプロリン，オキシプロリンの存在を毁め ず，アスパラギンの存在は增わしいとしている方，此の 3 者はいなれるニンヒドリンとの色調に特色があ、り落者 等は明かにその存在を溉め得大。

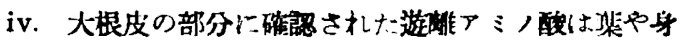
の部分に比、こでの種顛が少い。セリン,スレオニシ,シ スチン,ブロリン,ア大ハラギン酸, ヒスチヂン,フルギニ

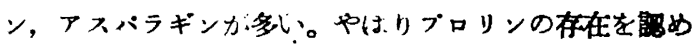
た点しかるかなりの航である点で武藤氏の報告と異る。

\section{哭 約}

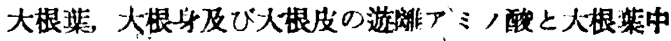

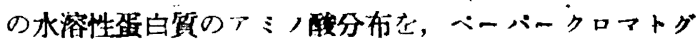
ラフ法により調くた。

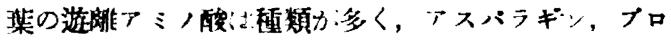

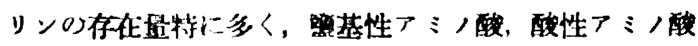
の量的多い。

葉の水溚性蛋白中にはアスハラギン，グルタミン酸が

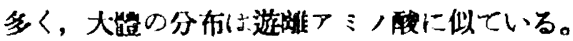

身の遊䠊厂ミノ酸にはグリシン，リヂン，フスハラギ ンが多く、プロリンオキシプロリンす存在茛めた。 皮の遊猅》ミ，酸は洁合に種類が少いか，ブロリンは

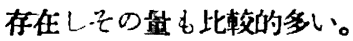

\section{等和文塥}

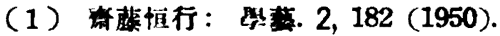

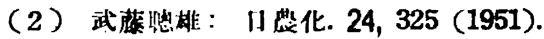

（3）武藤怒雄：日展化. 24，321 (1951).

(4) Consden, Gordin, Martin: Biochem. J. 38, 224 (1944); Dent: Biochem. J. 41, 240 (1947); Nature, 160, 80 (1947); Williams, Kirby : Science, 107, 481 (1948); Pratt, Jacqnes, Auclair: Science, 108, 213 (1948); Rockland, Dunn: Science, 109, 539 (1949). 